\title{
DEVELOPMENT OF A GOAT MILK YOGURT FLAVORED WITH THE MANGABA FRUIT (HANCORNIA SPECIOSA GOMES)
}

\author{
Elaine Alves Santos* \\ Vitória Regina Bessa* \\ Deborah Santesso Bonnas ${ }^{* *}$
}

\begin{abstract}
Goat's milk has characteristics that distinguish it from other species animal's milk. Its use combines the best features of digestibility and the possibility to be consumed by allergic people to cow's milk and its derivatives. This study aimed to evaluate the physical- chemical, microbiological and sensory yogurt made of goat's milk with added pulp and sweet mangaba (Hancornia speciosa Gomes ).This study also aimed to add the use of the fruits of Brazilian cerrado. Five concentrations of mangaba pulp and jam were employed: $0 \%$, $5 \%, 6 \%, 7 \%$, and $8 \%$. The indices of color, lipids, total soluble solids ( ${ }^{\circ} \mathrm{Brix}$ ), $\mathrm{pH}$, proteins and acidity were determined. Microbiological analyses were conducted on the yogurt to determine the presence of thermotolerant coliforms, aerobic mesophiles and Salmonella sp. A group of 50 untrained food tasters was used in the sensory analyses. A structured 5-point hedonic scale was employed, from 1 ("I disliked the product very much") to 5 ("I liked the product very much"). The acceptability index was also calculated. Regarding the yogurts flavored with mangaba pulp and jam, only the indices of color and total soluble solids presented significant differences. The microbiological analyses were compliant with Brazilian standards. The results of the sensory analysis were also satisfactory. This study concluded that goat milk yogurt flavored with mangaba pulp or jam is a promising alternative to those consumers who are allergic to cow milk, as well as to those who would like to include such product in their diet seeking a better digestibility.
\end{abstract}

KEYWORDS: Sensory analysis; Microbiological analysis; Physical and chemical analysis; Cerrado fruits.

\section{DESENVOLVIMENTO DE IOGURTE DE LEITE DE CABRA SABORIZADO COM MANGABA (HANCORNIA SPECIOSA GOMES)}

RESUMO: 0 leite de cabra apresenta características próprias que o distinguem do leite de outras espécies de animais. Seu uso agrega as características de melhor digestibilidade e possível utilização por pessoas alérgicas ao leite de vaca e seus derivados. Esse trabalho objetivou avaliar as características físico-químicas, microbiológicas e sensoriais de iogurtes produzidos com o leite de cabra com adição de polpa e doce da mangaba (Hancornia speciosa Gomes). Este estudo visou também agregar 0 aproveitamento das frutas do cerrado brasileiro. Foram utilizadas cinco concentrações $(0 \%, 5 \%, 6 \%, 7 \%$ e $8 \%)$ de polpa e doce de mangaba. No iogurte, foram determinados índice de cor, lipídeos, sólidos soluveis totais (graus Brix), pH, proteína e acidez. Foram realizadas avaliações microbiológicas de coliformes termotolerantes, aeróbios mesófilos e Salmonella $s p$ no iogurte. Os testes sensoriais foram realizados com um grupo de 50 provadores não treinados. Foi usada a escala hedônica estruturada de cinco pontos, com extremos 1 (desgostei muito) e 5 (gostei muito). Foi calculado ainda 0 índice de aceitabilidade. Para os iogurtes elaborados com polpa e doce de mangaba, apenas 0 índice de cor e $0{ }^{\circ}$ Brix obtiveram diferenças significativas. As análises microbiológicas se apresentaram de acordo com os padrões vigentes. Na avaliação sensorial, os resultados encontrados foram satisfatórios. Conclui-se que 0 iogurte de leite de cabra saborizado com polpa ou doce de mangaba representa uma alternativa promissora para os consumidores alérgicos ao leite de vaca e para aqueles que gostariam de incluir o produto em sua dieta, visando maior digestibilidade.

PALAVRAS-CHAVE: Análise sensorial; Análise microbiológica; Análise físico-química; Frutos do cerrado.

\footnotetext{
Doutoranda no Programa de Pós-graduação em Ciência e Tecnologia de Alimentos (PPGCTA/UFG), Goiânia; Técnica do laboratório de agroindústria do Instituto Federal de Educação Ciência e Tecnologia do Triângulo Mineiro, Campus Uberlândia, Brasil.

** Instituto Federal do Triângulo Mineiro Campus Uberlandia, Brasil.

${ }^{* * *}$ Doutorado em Ciências dos Alimentos pela Universidade Federal de Lavras; Docente do ensino básico técnico e tecnológico do Instituto Federal de Educação Ciência e Tecnologia do Triângulo Mineiro, Campus Uberlândia, Brasil. E-mail: deborahb@iftm.edu.br
} 


\section{INTRODUCTION}

Due to its excellent nutritional value, milk - a natural food - is considered a wholesome product. Not only does it provide the correctamount of essential amino acids for our development and the supplementation of our diets, but it also supplies us with proteins that are fundamental to nutrition and whose plastic function is to repair cells (BADARÓ 2007).

However, some people suffer from allergies to the proteins in cow milk, which are usually diagnosed during the first three years of life. Eliminating this type of product from one's diet is the solution to such problem. Nevertheless, milk is an important source of nutrition for children; thus, its nutrients must be replaced with another food source (MEDEIROS et al., 2004; RIBEIRO; RIBEIR0, 2001).

The protein composition of goat milk is similar to that of cow milk, but its decreased content of alpha-s1 casein promotes the formation of fine, soft milk clots - which eases the digestibility of such food product (MAREE, 1985). Therefore, the proportion of small-sized casein micelles is larger in goat milk than it is in cow milk, corroborating said good digestibility (GRZESIAK, 1997).

Ferreira et al. (2001) claim that goat milk also contains certain enzymes that convert carbohydrates into simple sugars and lactic yeast. These substances help to protect the intestines from the pathogenic action of bacteria.

Yogurt is one of the milk derivatives that are considered functional. It can be produced through the fermentation of milk by a symbiotic mixed culture of Lactobacillus bulgaricus and Streptococcus thermophiles, and both microorganisms are viable and abundant in the final product (MOREIRA, 1999).

The mangaba tree (Hancornia speciosa Gomes) is a tropical fruit plant. It is native to Brazil and can be found in various regions throughout the country, such as the Northeastern coastal tablelands and lowlands, as well as the Cerrado in the Center-Western, Northern and Southeastern regions. The word mangaba is of indigenous origin and means "a pleasant food to eat."
It is rich in iron and provides a good source of vitamin C (SILVA JUNIOR, 2004).

Although the mangaba tree produces latex, the fruit it bears - of exceptional flavor and aroma - is its main product in the Brazilian market, especially in the pulp, juice, and ice cream industries (SILVA JUNIOR, 2004).

Traditional yogurt, produced with fruit pulp, represents $33 \%$ of the entire Brazilian market (IOGURTES, 1995). Therefore, using Cerrado fruits to flavor it is an alternative that can increase the consumption of fruit and milk in the country.

In this context, the present study aimed to develop a goat milk yogurt flavored with mangaba pulp (Hancornia speciosa Gomes). The researchers attempted to improve the digestibility of the product and to enable people who are allergic to cow milk and its derivatives to consume it, as well as to boost the use of Cerrado fruits in Brazil, especially the mangaba.

\section{MATERIALS AND METHODS}

The present study was carried out at the Uberlândia Campus of the Instituto Federal de Educação, Ciência e Tecnologia do Triângulo Mineiro (IFTM), Brazil, between September and December, 2014.

The Ethics committee of the Centro Universitário do Triângulo (UNITRI) endorsed the project, which was conducted under Certificate of Introduction to Ethics Assessment (CAAE) serial number 320709013.7.0000.5565, ruling 808.971, as of 28th September, 2014.

\subsection{PULP AND MANGABA JAM PROCESSING}

The pieces of mangaba (Hancornia speciosa Gomes) were purchased at the municipal market of Aracaju (Sergipe, Brazil). They were packed in plastic bags, frozen, and transported in isothermal boxes before the start of the analyses. The basic processing, which was compliant with the local Good Manufacturing Practices (GUIA..., 2000), consisted of selecting, 
sanitizing, pulping, pasteurizing, and packaging the fruit.

The following methods were employed by the authors while treating the pieces of mangaba:

The unpeeled samples were sanitized with a 100 ppm sodium hypochlorite solution for 15 minutes; subsequently, they were peeled off manually with knives; the pulp was removed from the pieces of fruit, also manually; lastly, the pieces of fruit were pasteurized (at 65 degrees Celsius for 30 minutes) and cooled (at 7 degrees Celsius).

In order to make the jam, the researchers removed a total amount of 4.4 pounds of pulp from the mangaba samples. Thereafter, the product was heated (at $80^{\circ} \mathrm{C}$ ) and mixed with 1.1 pounds (453 grams) of granulated sugar. The pulp and the sugar contents were then manually homogenized, with continuous stirring. The total soluble solids value was measured throughout the entire process, until it reached the concentration level of 40 degrees Brix.

\subsection{YOGURT PROCESSING}

The goat milk used in the development of the yogurts was donated by the Universidade Federal de Uberlândia (UFU) after being collected from its herd. Rocha et al.'s (2008) methodology was adapted by the authors during the production stage. In order to flavor it, five different concentrations of mangaba pulp and jam (Hancornia speciosa Gomes) were employed: $0 \%$, $5 \%, 6 \%, 7 \%$, and $8 \%$.

\subsection{PHYSICAL AND CHEMICAL ANALYSES}

Physical and chemical analyses were carried out on the milk and on the formulations of yogurt developed. All analyses were conducted in triplicate.

The averages that presented any significant differences through the F-test were compared by the authors with the Scott-Knott test $(p<0.05)$. The computer software Sisvar, capable of providing analyses of variance (FERREIRA, 2003), was used in the process.

In order to analyze the $\mathrm{pH}$, a direct reading was performed by the researchers using a Gehaka PG 2000 digital benchtop pH meter (AOAC, 2012).

The technique of potentiometric titration was used to determine the acidity. Afterward, the researchers used the aforementioned $\mathrm{pH}$ meter, as well as a $0.1 \mathrm{~N} \mathrm{NaOH}$ solution, to titrate the products whose pH was up to 8.10 (AOAC, 2012).

Another direct reading was performed with an AM. 2.09 refractometer, with a Brix scale ranging from 0 degrees to 60 degrees Brix (ALFA MARE), to determine the Brix value (Aoac 2012).

In order to assess the color index of the product (which was based on the CIELAB system), another direct reading was conducted - with a CR-400 Utility Software chroma meter (KONICA MINOLTA) (AOAC, 2012).

The Kjeldahl method was employed to determine the protein content of the sample. The authors used a conversion factor of 6.38 in order to convert the nitrogen content obtained into proteins (AOAC, 2012).

Lastly, the lipid content was determined via Gerber method (AOAC, 2012).

\subsection{MICROBIOLOGICAL ANALYSES}

Microbiological analyses were carried out on the goat milk and on the formulations of yogurt developed. All analyses were conducted in triplicate. In order to determine the presence of thermotolerant coliforms, the authors followed Silva et al. (2010) methodology and used the Most Probable Number method (MPN/ml).

Later on, Silva et al (2010) methodology was employed once again; the Standard Plate Count method was used, through the Pour Plate technique, to detect aerobic mesophile microorganisms.

For the analysis of Salmonella $s p, 25 \mathrm{ml}$ of each treatment were homogenized in $225 \mathrm{ml}$ of buffered peptone water. Subsequently, the products were incubated at 37 degrees Celsius for 24 hours. The researchers also transferred 1.0 and $0.1 \mathrm{ml}$ aliquots of such suspensions into $10 \mathrm{ml}$ tetrathionate and Rappaport broths, respectively, with incubation 
temperatures of $37^{\circ} \mathrm{C}$ and $41.5^{\circ} \mathrm{C}$. The Streak Plate method on Petri dishes containing XLD (Xylose Lysine Deoxycholate) agar was also used. Biochemical tests were carried out on the problematic colonies (APHA, 2015).

Lastly, the authors calculated the amount averages of each microorganism studied and each treatment analyzed, in order to tabulate the results by means of descriptive statistics.

\subsection{SENSORY ANALYSIS}

For the sensory analysis, an Acceptance test with a structured 5-point hedonic scale was carried out, based on Dutcosky (1996) methodology. The points ranged from 1 ("I disliked the product very much") to 5 ("I liked the product very much").

Subsequently, tests were conducted at the sensory laboratory of the Uberlândia Campus of the Universidade Federal de Uberlândia. The authors surveyed 50 untrained food tasters, who signed an Informed Consent Form before taking part in the study.

Said food tasters were randomly given yogurt sample cups corresponding to the five treatments tested (concentrations of $0 \%, 5 \%, 6 \%, 7 \%$, and $8 \%$ of mangaba pulp and jam) and a form, which should be filled in during the sensory analysis. Each cup carried random three-digit codes. The attributes flavor, odor, color, texture, and overall impression of each sample were assessed, and their results were subjected to an analysis of variance and the Scott-Knott test (DUTCOSKY, 2011).

For the calculation of the index of Consumer Acceptability of the product, the authors employed the equation ICA (\%) =A $A 100 / B$, in which "A" was the average grade obtained by the product, and " $B$ " was the highest grade the product could receive. Any ICAs $\geq 70 \%$ were considered to be positive (DUTCOSKY, 2011).

\section{RESULTS AND DISCUSSION}

\subsection{PHYSICAL AND CHEMICAL CHARACTERIZA-} TION OF THE GOAT MILK AND THE YOGURTS

Table 1 presents the averages found on the physical and chemical analyses conducted by the authors on the pasteurized goat milk.

Table 1. Characterization of the pasteurized goat milk

\begin{tabular}{cccccc}
\hline Goat milk & TSS & pH & Lipids & Protein & Acidity \\
\hline Sample & 6 & 7.09 & $1.9 \%$ & $3.62 \%$ & $0.1632 \%$ \\
\hline
\end{tabular}

While developing this study, it was considerate the overall parameters established by the Brazilian technical regulations for the manufacturing, identification, and quality control of goat milk (BRASIL, 2000a).

For the total soluble solids (TSS) content, the goat milk analyses found the average value of 6 degrees Brix.

The average $\mathrm{pH}$ of the goat milk was above what is recommended by the Brazilian law, which is 6.5 (BRASIL, 2000b). During their analyses of frozen goat milk, Gomes et al. (1997) found averages ranging from 6.60 to 6.45 .

Regarding the parameter lipids, it was observed that the average found was below that which the law recommends. Such finding may be explained by the dry climate of the region where the raw materials were collected - which influenced the lipid content of the goat milk. In their study, Andrade et al. (2008) analyzed the microbiological and physical and chemical characteristics of goat milk bottles that underwent a process of slow pasteurization and freezing after being properly packed. They found a lipid content higher than that of this study: $3.7 \%$ in the raw milk and $3.5 \%$ in the frozen milk.

While assessing the protein content, the authors found an average within standards of what is required by law (BRASIL, 2000a): a minimum of $2.8 \%$. Pereira et al. (2005), in their study of the physical 
and chemical parameters of the goat milk distributed by the social program "Milk of Paraíba" in the Cariri region of the Brazilian state of Paraíba, found a protein content of $3.3 \%$.

As for the assessment of the acidity of the pasteurized goat milk, it was also found within standards required by Brazilian law (BRASIL, 2000a): ranging from $0.13 \%$ to $0.18 \%$. Pereira et al. (2005) had similar results, with a titratable acidity of $0.16 \%$.

Table 2 presents the results of the physical and chemical analyses on the yogurt flavored with mangaba pulp and jam.

Table 2. Physical and chemical analyses of the goat milk yogurt flavored with mangaba pulp and jam (Hancornia speciosa Gomes)

\begin{tabular}{ccccccccc}
\hline Treatments & $\mathrm{L}^{*}$ & $\mathrm{a}^{*}$ & $\mathrm{~b}^{*}$ & Lipids & TSS & $\mathrm{pH}$ & Protein & Acidity \\
\hline Control treatment & $32.93 \mathrm{~b}$ & $-3.02 \mathrm{a}$ & $4.97 \mathrm{a}$ & $2.2 \mathrm{a}$ & $16.0 \mathrm{c}$ & $3.64 \mathrm{a}$ & $2.32 \mathrm{a}$ & $0.90 \mathrm{a}$ \\
5\% Pulp & $31.71 \mathrm{a}$ & $-2.58 \mathrm{~b}$ & $5.77 \mathrm{~b}$ & $2.3 \mathrm{a}$ & $15.0 \mathrm{~b}$ & $3.56 \mathrm{a}$ & $2.22 \mathrm{a}$ & $0.87 \mathrm{a}$ \\
6\% Pulp & $32.40 \mathrm{~b}$ & $-2.70 \mathrm{~b}$ & $5.73 \mathrm{~b}$ & $2.5 \mathrm{a}$ & $16.07 \mathrm{c}$ & $3.58 \mathrm{a}$ & $2.42 \mathrm{a}$ & $0.86 \mathrm{a}$ \\
7\% Pulp & $32.74 \mathrm{~b}$ & $-2.66 \mathrm{~b}$ & $5.76 \mathrm{~b}$ & $2.3 \mathrm{a}$ & $14.0 \mathrm{a}$ & $3.57 \mathrm{a}$ & $2.49 \mathrm{a}$ & $0.85 \mathrm{a}$ \\
8\% Pulp & $30.87 \mathrm{a}$ & $-2.47 \mathrm{c}$ & $6.03 \mathrm{c}$ & $2.0 \mathrm{a}$ & $19.0 \mathrm{e}$ & $3.59 \mathrm{a}$ & $2.22 \mathrm{a}$ & $0.86 \mathrm{a}$ \\
5\% Jam & $31.39 \mathrm{a}$ & $-2.32 \mathrm{~d}$ & $5.90 \mathrm{c}$ & $2.5 \mathrm{a}$ & $16.5 \mathrm{c}$ & $3.59 \mathrm{a}$ & $2.28 \mathrm{a}$ & $0.87 \mathrm{a}$ \\
$6 \%$ Jam & $31.16 \mathrm{a}$ & $-2.21 \mathrm{~d}$ & $5.80 \mathrm{~b}$ & $2.2 \mathrm{a}$ & $16.0 \mathrm{c}$ & $3.59 \mathrm{a}$ & $2.29 \mathrm{a}$ & $0.88 \mathrm{a}$ \\
$7 \%$ Jam & $30.57 \mathrm{a}$ & $-2.16 \mathrm{~d}$ & $5.76 \mathrm{~b}$ & $2.1 \mathrm{a}$ & $17.0 \mathrm{~d}$ & $3.60 \mathrm{a}$ & $2.52 \mathrm{a}$ & $0.85 \mathrm{a}$ \\
8\% Jam & $30.77 \mathrm{a}$ & $-2.08 \mathrm{e}$ & $5.93 \mathrm{c}$ & $2.1 \mathrm{a}$ & $16.0 \mathrm{c}$ & $3.61 \mathrm{a}$ & $2.38 \mathrm{a}$ & $0.91 \mathrm{a}$ \\
\hline
\end{tabular}

Averages followed by the same letter in the columns do not present any statistical differences according to the Scott-Knott test $(\mathrm{p}<0.05)$

$L^{*}=$ luminance; $L=0$ : the treatment was completely black; $L=100$ : the treatment was completely white

$\mathrm{a}^{*}(+)=$ tendency for the color red; $A(-)=$ tendency for the color green

$\mathrm{b}^{\star}(+)=$ tendency for the color yellow; $\mathrm{B}(-)=$ tendency for the color blue

Currently, there is no specific law in Brazil that governs the production of yogurt with goat milk. For this study, the authors complied with the overall parameters established by the Brazilian standards of identity and quality for fermented milks (BRASIL 2000b).

The researchers observed that the yogurts flavored with pulp presented a significant difference regarding the parameter luminance. As for the products flavored with mangaba jam, no major difference was detected; the samples' luminance was even less expressive. The treatments with $5 \%, 6 \%$, and $7 \%$ pulp displayed a greater tendency for the color green $\left(-\mathrm{a}^{*}\right)$. The remaining treatments were also green; however, their averages were lower when compared to the aforementioned yogurt formulations and the control sample.

There were also major differences among the treatments regarding the parameter tendency for the color yellow $\left(+b^{\star}\right)$; the authors noted the color was more intense in the formulation with $8 \%$ mangaba pulp, as well as the ones with $5 \%$ and $8 \%$ mangaba jam. All samples presented a predominance of shades of the color yellow - which may be explained by the addition of mangaba pulp and jam to the yogurt (given that both exhibit such tones).

The average of the lipid content also did not present any major differences among the treatments, varying between $2.5 \%$ and $2.0 \%$. Similar fat contents were found by Marinho et al. (2012) in their goat milk 
yogurt flavored with umbu pulp: $2.16 \%, 2.20 \%$, and $2.13 \%$.

The averages for the total soluble solids (TSS) content of the yogurt, measured in degrees Brix, presented a considerable difference. The treatment with $8 \%$ pulp displayed the highest content.

The average $\mathrm{pH}$ of the product did not present any significant differences, ranging from 3.56 to 3.64 . There was no modification in such value, even after the concentrations of pulp and jam in the yogurt were increased. The $\mathrm{pH}$ values obtained were compliant with the average established by the Brazilian law: from 3.6 to 4.5 (BRASIL 2000b). Marinho et al. (2012) detected superior values, with variations between 3.87 and 4.05 .

Regarding the assessment of the proteins, the researchers did not observe any major differences between the treatments, with averages ranging from $2.22 \%$ to $2.49 \%$. Laguna and Egito (2008) found contents even lower than those found by this study: while analyzing a goat milk yogurt produced with tropical fruits, they noted that the products presented $1.78 \%$ proteins.

Lastly, regarding the parameter acidity, the yogurt samples did not present any major differences; the contents varied between $0.85 \%$ and $0.91 \%$. Such results are compliant with the Brazilian Law (BRASIL, $2000 \mathrm{~b}$ ), which sets acidity limits between $0.60 \%$ and $1.5 \%$ for yogurts. Inferior amounts were detected by Marinho et al. (2012) in their analyses of a goat milk yogurt flavored with umbu pulp, where the acidity ranged from $0.76 \%$ to $0.80 \%$.

\subsection{MICROBIOLOGICAL CHARACTERIZATION OF THE GOAT MILK AND THE YOGURTS}

All the analyses conducted on the goat milk were compliant with the Brazilian legal standards, based on Resolution RDC No. 12 as of 2nd January, 2001, issued by ANVISA, the Brazilian Health Surveillance Agency (BRASIL, 2001). Such resolution sets forth a maximum index of $4 \mathrm{NMP} / \mathrm{ml}$ for the analysis of thermotolerant coliforms. The product must also be clear of Salmonella sp.

Picoli et al. (2006) found, in their study on the quantification of thermotolerant coliforms (present in different production stages of Minas cheese made with goat milk), similar results to those of this research indicating the absence of such microorganism.

Oliveira et al. (2005) found similar results in their study on the physical -chemical and microbiological quality of a goat milk pasteurized at a ultra-hightemperature, marketed in the city area of Ribeirão Preto (São Paulo, Brazil).

Table 3 present the results of the microbiological analyses on the goat milk yogurts flavored with mangaba pulp and jam (Hancornia speciosa Gomes).

The results were compliant with the Brazilian

Table 3. Microbiological analysis of the goat milk yogurt flavored with mangaba pulp and mangaba jam (Hancornia speciosa Gomes)

\begin{tabular}{cccc}
\hline Treatments & $\begin{array}{c}\text { Aerobic mesophiles } \\
(\text { CFU/ml) }\end{array}$ & $\begin{array}{c}\text { Thermotolerant coliforms } \\
\text { (MPN/ml) }\end{array}$ & $\begin{array}{c}\text { Salmonella sp. } \\
\text { (Absent in 25ml) }\end{array}$ \\
\hline Control treatment & $<1.0 \times 10^{1}$ & $<3.0 \times 10^{1}$ & Absent \\
$5 \%$ Pulp & $6.6 \times 10^{1}$ & $<3.0 \times 10^{1}$ & Absent \\
$6 \%$ Pulp & $6.6 \times 10^{1}$ & $<3.0 \times 10^{1}$ & Absent \\
$7 \%$ Pulp & $6.6 \times 10^{1}$ & $<3.0 \times 10^{1}$ & Absent \\
$8 \%$ Pulp & $3.3 \times 10^{1}$ & $<3.0 \times 10^{1}$ & Absent \\
$5 \%$ Jam & $6.6 \times 10^{1}$ & $<3.0 \times 10^{1}$ & Absent \\
$6 \%$ Jam & $1.33 \times 10^{1}$ & $<3.0 \times 10^{1}$ & Absent \\
$7 \%$ Jam & $1.33 \times 10^{1}$ & $<3.0 \times 10^{1}$ & Absent \\
$8 \%$ Jam & $1.66 \times 10^{1}$ & $<3.0 \times 10^{1}$ & Absent \\
\hline
\end{tabular}


legal standards, based on Resolution RDC No. 12 as of 2nd January, 2001 (BRASIL, 2001). Such resolution sets forth a maximum index $10 \mathrm{NMP} / \mathrm{ml}$ for the analysis of thermotolerant coliforms. The product must also be clear of Salmonella sp. in $25 \mathrm{ml}$.

In Brazil, there is no legal standard that governs the presence of aerobic mesophilic microorganisms. The results of the authors' analyses can demonstrate the hygienic-sanitary quality of the product, which shows that the yogurt processing conducted during this study was compliant with what is recommended by the Good Manufacturing Practices.

Although the Brazilian law does not set specific parameters for this type of microorganism, Cesarino et al. (2010) claim that the vast majority of foodborne pathogenic bacteria is mesophile; also, large amounts of such microorganism in the final product may indicate the presence of contaminants.
Oliveira et al. (2013) did not detect any thermotolerant coliforms in two of the batches they analyzed in their study. Only one of them showed amounts larger than what is recommended by law: $240 \mathrm{MPN} / \mathrm{ml}$ for total coliforms and $6.4 \mathrm{MPN} / \mathrm{ml}$ for thermotolerant coliforms.

In their study on the development of a yogurt flavored with Cerrado fruits, Rocha et al. (2008) did not detect the presence of Salmonella sp.

\subsection{SENSORY CHARACTERIZATION}

\subsubsection{Acceptance of the yogurt flavored with mangaba pulp (Hancornia speciosa Gomes)}

Table 4 presents the results of the Acceptance test on the goat milk yogurt.

Regarding the attribute appearance, the

Table 4. Results of the Acceptance test of the goat milk yogurt flavored with mangaba pulp (Hancornia speciosa Gomes)

\begin{tabular}{cccccc}
\hline Treatments (\%) & Appearance & Aroma & Flavor & Color & Overall impression \\
\hline Control treatment & $3.8 \mathrm{~b}$ & $3.7 \mathrm{~b}$ & $3.6 \mathrm{~b}$ & $3.9 \mathrm{~b}$ & $3.9 \mathrm{~b}$ \\
5 Pulp & $3.3 \mathrm{a}$ & $2.8 \mathrm{a}$ & $2.8 \mathrm{a}$ & $3.3 \mathrm{a}$ & $3.2 \mathrm{a}$ \\
6 Pulp & $3.8 \mathrm{~b}$ & $3.3 \mathrm{a}$ & $3.3 \mathrm{a}$ & $3.6 \mathrm{~b}$ & $3.7 \mathrm{~b}$ \\
7 Pulp & $3.4 \mathrm{a}$ & $3.1 \mathrm{a}$ & $3.1 \mathrm{a}$ & $3.6 \mathrm{~b}$ & $3.4 \mathrm{a}$ \\
8 Pulp & $3.6 \mathrm{~b}$ & $3.5 \mathrm{~b}$ & $3.5 \mathrm{~b}$ & $3.6 \mathrm{~b}$ & $3.6 \mathrm{~b}$ \\
\hline
\end{tabular}

Averages followed by the same letter in the columns do not present a statistical difference according to the Scott-Knott test $(p<0.05)$

treatments presented a significant difference. The control sample, as well as treatments with $6 \%$ and $8 \%$ pulp, were the most praised samples by the food tasters among all the options.

The attributes aroma and flavor also experienced varying levels of acceptance. The control sample and the treatment with $8 \%$ pulp were the most praised by the food tasters.

In the assessment of the color of the yogurt, the authors noted that there was no major difference between the levels of acceptance of the treatments with $6 \%, 7 \%$, and $8 \%$ pulp; all three were praised by the tasters. Only treatment with $5 \%$ pulp displayed such difference, receiving lower grades when compared to the other treatments.

Lastly, the authors assessed the attribute overall impression. They could observe that the control sample, as well as treatments with $6 \%$ and $8 \%$ pulp, presented a significant difference in acceptance when compared to the remaining options; all three were highly praised by the food tasters: their grades ranged from 3 ("I neither liked nor disliked the product") to 4 ("I liked 
the product"). The formulation with $5 \%$ pulp received the lowest grade - which may be explained by the smaller percentage of mangaba pulp in this treatment, which gave the final product softer colors and a bland flavor (which were unpleasant to the tasters).

\subsubsection{Acceptance of the yogurt flavored with mangaba jam (Hancornia speciosa Gomes)}

Table 5 presents the results of the Acceptance test conducted by the authors on the goat milk yogurt flavored with mangaba jam (Hancornia speciosa Gomes).

Table 5. Results of the Acceptance test of the goat milk yogurt flavored with mangaba jam (Hancornia speciosa Gomes)

\begin{tabular}{cccccc}
\hline Treatments (\%) & Appearance & Aroma & Flavor & Color & Overall impression \\
\hline Control treatment & $3.9 \mathrm{~b}$ & $3.7 \mathrm{a}$ & $3.6 \mathrm{a}$ & $3.9 \mathrm{a}$ & $3.82 \mathrm{~b}$ \\
$5 \mathrm{Jam}$ & $3.7 \mathrm{~b}$ & $3.7 \mathrm{a}$ & $3.3 \mathrm{a}$ & $3.7 \mathrm{a}$ & $3.6 \mathrm{~b}$ \\
$6 \mathrm{Jam}$ & $3.4 \mathrm{a}$ & $3.4 \mathrm{a}$ & $3.3 \mathrm{a}$ & $3.6 \mathrm{a}$ & $3.3 \mathrm{a}$ \\
$7 \mathrm{Jam}$ & $3.5 \mathrm{a}$ & $3.6 \mathrm{a}$ & $3.4 \mathrm{a}$ & $3.6 \mathrm{a}$ & $3.5 \mathrm{a}$ \\
$8 \mathrm{Jam}$ & $3.6 \mathrm{a}$ & $3.6 \mathrm{a}$ & $3.4 \mathrm{a}$ & $3.5 \mathrm{a}$ & $3.9 \mathrm{~b}$ \\
\hline
\end{tabular}

Averages followed by the same letter in the columns do not present a statistical difference according to the Scott-Knott test $(p<0.05)$

Regarding the attribute appearance, the treatments presented major differences in the level of acceptance. The control sample and the treatment with $5 \%$ jam received the highest grades.

In their assessment of the level of acceptance based on the attributes aroma, flavor, and color, the authors did not detect any significant differences. As for the overall impression, they could note that the control sample, as well as treatments $5 \%$ and $8 \%$, obtained approximate grades to one another; such treatments did, however, present differences when compared to the remaining options.

The grades obtained - 3 ("I neither liked nor disliked the product") and 4 ("I liked the product") demonstrate that the yogurt received a positive feedback from the food tasters.

\subsubsection{Index of consumer acceptability of the goat milk yogurt flavored with mangaba pulp and jam (Hancornia speciosa Gomes)}

Tables 6 and 7 present the results of the Index of Consumer Acceptability conducted by the authors for the goat milk flavored with mangaba pulp and jam (Hancornia speciosa Gomes). According to Teixeira et al. (1987) and Dutcosky (1996), a product must have an Index of Consumer Acceptability (ICA) greater than or equal to $70 \%$ in order to be sensuously accepted.

Table 6. Index of consumer acceptability of the goat milk yogurt flavored with mangaba pulp (Hancornia speciosa Gomes)

\begin{tabular}{cc}
\hline Treatments & $\begin{array}{c}\text { Index of consumer } \\
\text { acceptability (\%) }\end{array}$ \\
\hline Control treatment & 75.60 \\
\hline $5 \%$ Pulp & 61.60 \\
\hline $6 \%$ Pulp & 66.40 \\
\hline $7 \%$ Pulp & 70.80 \\
\hline $8 \%$ Pulp & 71.20 \\
\hline
\end{tabular}

As shown by Table 6, the indices of consumer acceptability for the yogurts flavored with mangaba pulp (Hancornia speciosa Gomes) were satisfactory (for the control sample and the treatments with $7 \%$ 
and $8 \%$ pulp). Only treatments with $5 \%$ and $6 \%$ pulp displayed percentages inferior to those recommended by law. Such outcome is a consequence of the lower concentrations of pulp carried by said treatments, which gave them an undistinctive flavor.

Table 7. Index of consumer acceptability of the goat milk yogurt flavored with mangaba jam (Hancornia speciosa Gomes)

\begin{tabular}{cc}
\hline Treatments & $\begin{array}{c}\text { Index of consumer } \\
\text { acceptability (\%) }\end{array}$ \\
\hline Control treatment & 75.60 \\
$5 \% \mathrm{Jam}$ & 68.00 \\
$6 \% \mathrm{Jam}$ & 70.40 \\
$7 \% \mathrm{Jam}$ & 72.00 \\
$8 \% \mathrm{Jam}$ & 72.00 \\
\hline
\end{tabular}

The indices of consumer acceptability for the yogurt flavored with mangaba jam (Hancornia speciosa Gomes) showed promising results, as shown by Table 7. Only the index of the treatment with $5 \%$ jam was lower than $70 \%$.

The control sample was met with the highest ICA, followed by the treatments with $6 \%, 7 \%$, and $8 \%$ jam. Such outcome may indicate how the yogurt market can be improved.

Galdino et al. (2010) claim that goat milk still has limited use in the yogurt industry. However, positive study outcomes have proven that such type of milk may become a resource for the dairy industry in the future.

\section{CONCLUSION}

With this study, the researchers were able to conclude that goat milk yogurts flavored with mangaba pulp or jam are a promising alternative to consumers who are allergic to cow milk, as well as to those who wish to improve their diets by ingesting such products.

The outcomes of the physical and chemical and microbiological analyses conducted on the yogurt developed were compliant with the Brazilian governing laws.

The results of the sensory analyses carried out on the samples studied were also satisfactory. The average responses obtained for the yogurt flavored with both mangaba pulp and jam (Hancornia speciosa Gomes) proved that the product was praised by the food tasters surveyed. Moreover, they may indicate the possible applications of Cerrado fruits.

Lastly, the study results may contribute with information to the development of new products that may bear interesting nutritional and functional properties.

\section{ACKNOWLEDGEMENTS}

The authors gratefully acknowledge the support of the development of this work, FAPEMIG by granting research scholarship.

\section{REFERENCES}

ANDRADE, P. V. D.; SOUZA, M. R.; PENNA, C. F. A. M.; FERREIRA, J. M. Características microbiológicas e físico-químicas do leite de cabra submetido à pasteurização lenta pós-envase e ao congelamento. Ciência Rural, v.38, n. 5; p. 1424-1430, 2008.

APHA - AMERICAN PUBLIC HEALTH ASSOCIATION. Committee on Microbiological for Foods. Compendium of methods for the microbiological examination of foods. Washington: American Public Health Association. 5. ed., 2015.

AOAC - ASSOCIATION OF OFFICIAL ANALYTICAL CHEMISTRY. Official methods of analysis of AOAC international, Maryland : AOAC International. 19. ed., 2012.

BAdARÓ, A. C. L.; ARAúJO, T. F.; CARVALHO, A. F. Análise da contaminação microbiológica, mesófilos proteolíticos e lacto fermentadores do leite cru 
comercializado no município de Ipatinga. Revista do Instituto de Laticínios Cândido Tostes, v. 62, n.357, p. 293-299, 2007.

BRASIL. Agência Nacional de Vigilância Sanitária. Resolução $\mathrm{n}^{0} 12$ de 02 de janeiro de 2001. Aprova 0 regulamento técnico sobre padrões microbiológicos para alimentos. Diário Oficial da União, Brasília, 10 de janeiro de 2001. Seção 1, p. 45-53.

BRASIL. Ministério da Agricultura, Pecuária e Abastecimento. MAPA. Instrução Normativa $\mathrm{n}^{\circ} 37$, de 31 de outubro de 2000. Regulamento técnico de identidade e qualidade do leite de cabra. Diário Oficial da União, Brasília, DF, 31 de out. 2000a. Seção 1, p. 23.

BRASIL. Ministério da Agricultura Pecuária e Abastecimento. MAPA. Resolução $\mathrm{n}^{0} 5$ de 13 de novembro de 2000. Padrão de Identidade e Qualidade de Leites Fermentados, Diário Oficial da União, Brasília, DF, 13 de nov. de 2000b. Seção 1, p. 9-12 b.

CESARINO, M. L., SOARES, K. M. P.; SILVA, J. B. A. Avaliação de parâmetros de qualidade microbiológica de bebidas lácteas comercializadas na cidade de Mossoró-RN. PUBVET, 111. ed. v.4, n.6, Art. 747, 2010. Disponível em: <http://www.pubvet.com.br/ uploads/b5f8a1a8c6335f1c5ae1f184f6069500.pdf>. Acesso em: 15 jan. 2015.

DUTCOSKY, S. D. Análise sensorial de alimentos. 3. ed. Curitiba: Champagnat, 2011. 426p.

FERREIRA, C. L. L. F.; MALTA, H. L.; CARELI, R. T.; DIAS, A. S; GUIMARÃES, A.; JACOB, F.; CUNHA, R. M.; PEREIRA, S.; OLIVEIRA, S. Verificação da qualidade físico-química e microbiológica de alguns iogurtes vendidos na região de Viçosa. Revista do Instituto de Laticínios Cândido Tostes, v.56, n.321, p. 152-158, 2001.

FERREIRA, D. F. Sistema para análise de variância para dados balanceados (SISVAR versão 4.3). Lavras: Ed. da UFLA, 2003.
GALDINO, P. 0.; GALDINO, P. 0.; FERNANDES, T. K. S. OLIVEIRA, M. R. T.; ROCHA, A. P. T. Caracterização sensorial de iogurte enriquecido com polpa da palma forrageira (Napolea cochenillifera). Revista Verde de Agroecologia e Desenvolvimento Sustentável, v. 5, n. 5, p. 53-60, 2010.

GOMES, M. I. F. V.; BONASSI, I. A.; ROÇA, R. 0. Características químicas, microbiológicas e sensoriais de leite de cabra congelado, Ciência e Tecnologia de Alimentos, 17. ed., n. 2, p. 111-114, 1997.

GRZESIAK, T. Lait de chévre, lait d'avenir pour les nourrisson. In: INTÉRÊTS nutritionnel et diététique du lait de chévre, Paris: INRA, 1997. p. 201.

GUIA para elaboração do plano APPCC: frutas, hortaliças, e derivados. Brasília: SENAI/DN, 2. ed. 2000. (Série Qualidade e Segurança Alimentar, Projeto APPCC Indústria, Convênio SNI/SEBRAE).

IOGURTES e bebidas lácteas: alimentos e tecnologia. 9. ed. [s.l.; s.n], 1995. v. 57, p. 20-51,

LAGUNA, L. E.; EGITO, A. S. logurte de leite de cabra adicionado de frutas tropicais. Sobral, CE: Embrapa Caprinos, 2006. (Circular Técnica, 32). Disponível em: <www.cnpc.embrapa.br>. Acesso em: 05 jan. 2015.

MAREE, H. P. Goat milk and its use as a hypoallergenic infant food. Dairy Goat Journal, v. 63, n. 12, p. 864898, 1985.

MARINHO, M. V. M.; FIGUEIRÊDO, R. M. F.; QUEIROZ, J. M.; SANTIAGO, V. M. S.; GOMES, J. P. Análise físicoquímica e sensorial de iogurte de leite de cabra com polpa de umbu. Revista Brasileira de Produtos Agroindustriais, Campina Grande, v. 14. n. ed. especial, p. 497-510, 2012.

MEDEIROS, L. C. S.; SPERIDIÃO, P. G. L.; SDEPANIAN, V. L.; NETO, U. F.; MORAIS, M. B. Ingestão de nutrientes e estados nutricional de crianças em dieta isenta de leite de vaca e derivados. Jornal de Pediatria, v. 80, n. 5, p. 363-370, 2004. 
MOREIRA, S. R.; SCHWAN, R.F.; CARVALHO, E.P.; FERREIRA, C. Análise microbiológica e química de iogurtes comercializados em Lavras - MG. Ciência e Tecnologia de Alimentos, v.19, n.1, p. 147152, 1999. Disponível em: <http://www.scielo. br/scielo.php?script=sci_abstract\&pid=S0101$20611999000100027 \& \operatorname{lng}=p t \& t \mid n g=p t>$. Acesso em: 06 mar. 2015.

OLIVEIRA, F. M.; LYRA, I. N.; ESTEVES, G. S. G. Avaliação microbiológica e físico-química de iogurtes de morango industrializados e comercializados no município de Linhares - ES. Revista Brasileira de Produtos Agroindustriais, v. 15, n. 2, p. 147-155, 2013.

OLIVEIRA, M. A.; FÁVAR0, R. M. D.; OKADA, M. M.; ABE, L. T.; IHA, M. H. Qualidade físico-química e microbiológica do leite de cabra pasteurizado e Ultra Alta Temperatura, comercializado na região de Ribeirão Preto-SP. Revista do Instituto Adolfo Lutz, v. 64, n. 1, p.136-141, 2005.

PEREIRA, R. Â. G.; QUEIROGA, R. de C. R. E.; VIANNA, R. P. T.; OLIVEIRA, M. E. G. Qualidade química e física do leite de cabra distribuído no Programa Social "Pacto Novo Cariri" no Estado da Paraíba. Revista do Instituto Adolfo Lutz, v. 64, n. 2, p. 205-211, 2005.

PICOLI, S. U.; BESSA, M. C.; CASTAGNA, S. M. F.; GOTTARDI, C. P. T.; SCHMIDT, V.; CARDOSO, M. Quantificação de coliformes, Staphylococcus aureus e mesófilos presentes em diferentes etapas da produção de queijo frescal de leite de cabra em laticínios. Ciência Tecnologia de Alimentos, v. 26, n. 1, p. 64-69, 2006.

RIBEIR0, E. L. A.; RIBEIR0, H. J. S. S. Uso nutricional e terapêutico do leite de cabra. Semina: Ciências Agrárias, v. 22, n. 2, p. 229-235, 2001.

ROCHA, C.; COBUCCI, R. M.; MAITAN, V. R.; SILVA, 0. C. Elaboração e avaliação de iogurte sabor frutos do cerrado. Boletim do Centro de Pesquisa de Processamento de Alimentos, v. 26, n. 2, p. 255266, 2008.
SILVA JUNIOR, J. F. A cultura da mangaba. Revista Brasileira de Fruticultura, v. 26, n.1, p. 1-192, 2004.

SILVA, N.; JUNQUEIRA, V. C. A.; SILVEIRA, N. F. A. Manual de métodos de análises microbiológicas de alimentos. 2. ed. São Paulo: Varela, p. 317, 2010.

TEIXEIRA, E.; MEINERT, E.; BARBETTA, P. A. Análise sensorial dos alimentos, Florianópolis: UFSC, 1987. p. 182.

Recebido em: 23 de fevereiro de2017 Aceito em: 03 de maio de 2017 